Olena Bulgakova, PhD (Candidate of Psychological Sciences), associate professor, Department of Social work and HR-management, Odessa National Polytechnic University, 1, Shevchenko avenue, Odesa, Ukraine

\title{
THEORETICAL AND METHODOLOGICAL BASIS FOR DEFINING THE MEANING OF THE CONCEPT "PSYCHOLOGICAL READINESS"
}

The concept of psychological readiness is considered from the standpoint of the methodological principles of determinism, the unity of consciousness and activities, the principle of the development based on reciprocal relations in the dyad «activity - reflection». The review of the issue in accordance with the categories of the common, the special and the singular provided the opportunity of distinguishing the elements of the general idea "to be ready for something", its concretised subjective basis and the degree of success in mastering the requirements of the relevant activities in the concept. It is noted that the dialectics of the common, the special and the singular is reproduced in the selection of the nearest genus in the formulation of definitions. The considerations on the concept of psychological readiness in the context of the notions "state", "mental state", "subjective rationality", "personality", "activities" are presented in the paper. It has been concluded that psychological readiness is as a complex internal personality-oriented phenomenon. Its main characteristics is the attitude towards oneself as towards a doer. It reproduces the experience of participating in the interactive events of the subject-subject and subject-object relations of social life. Thus, psychological readiness has subjective nature, in the light of which the considered concept gets the characteristics of experiencing its own subjectivity in the context of the desired and the assumed activities situation having certain degree of personal significance.

Keywords: psychological readiness, social interaction, a system of relations, subjectivity.

Подано до редакиії 08.04.2016

УДК: 159.98:78.01

Алла Леонідівна Весельська, асистент кафедри соиіальної та практичної психологї̈, Житомирський державний університет імені Івана Франка, вул. Велика Бердичівська, 40, м. Житомир, Україна

\section{ПСИХОЛОГІЧНА МОДЕЛЬ РОЗУМІННЯ МУЗИЧНИХ ТВОРІВ: СТРУКТУРА ТА КОМПОНЕНТНИЙ СКЛАД}

Розуміння музичного твору є складним процесом, де поєднуються емоційна та інтелектуальна сторони, зміст музичного матеріалу й особливості особистості. Ця єдність ускладнює процес розуміння та зумовлює потребу в структуруванні та уточненні компонентів загальної моделі розуміння, яка й визначає специфіку та результативність сприймання творів мистецтва. У статті проводиться аналіз теоретичних підходів та емпіричних досліджень з питань сприймання та розуміння музичних творів. Пропонується модель розуміння музичних творів, щзо включає когнітивний, операціональний та регулятивно-особистісний компоненти. Обгрунтовується зміст кожного компоненту розуміння музики.

Ключові слова: розуміння музичних творів, структура розуміння, когнітивний, операціональний та регулятивно-особистісний компоненти розуміння.

Зростання обсягу музичної інформації, яку людина сприймає у повсякденному житті, визначає актуальність дослідження процесів сприймання та розуміння. Музика тиражується та репродукується у повсякденному житті засобами масової інформації, використовується як фон для подачі інформації, наприклад, у рекламі; стає засобом спілкування у молодіжних субкультурах.

Розуміння музичного твору - це складний процес, де поєднуються емоційна та інтелектуальна сторони, зміст музичного матеріалу й особливості особи- стості. Ця єдність ускладнює процес розуміння та зумовлює потребу у структуруванні та уточненні компонентів загальної моделі розуміння, яка й визначає специфіку та результативність сприймання творів мистецтва.

У загальному вигляді проблема сприймання та розуміння музики розкривається у дослідженнях 3 різних галузей психології: психофізіології, музичної психології, психології мистецтва, інформаційної естетики тощо; висвітлюється як у вітчизняних (A. Г. Костюк, С. Н. Бєляєва-Екземплярська, 
М. Г. Арановський, А. Л. Готсдинер, А. Н. Сохор, €. Н. Назайкінський, Л. Л. Бочкарьов, Г. В. Іванченко), так і у зарубіжних (Р. Арнхейм, Г. Н. Кечхуашвілі, А. Моль, Р. Н. Бос-тром) наукових підходах.

Існуючі моделі слухання музики грунтуються на порівнювальній структурі перцептивного акту, що відображає багатомірність і багаторівневість музичного твору. Слухацьку діяльність уявляють і як слуховий аналіз твору, де одиницею виміру є звуковий об'єкт, і як процес схематизації і спрощення інформації, яка об'єктивно міститься в музичному творі. Відомі праці з вивчення процесу сприймання музики як специфічного виду перцепції [3; 8], визначення елементарних структур музичного сприймання [12], особливостей сприймання мелодії [10]. Зауважимо, що тривалий час проблеми сприймання і розуміння музичного твору розглядалися окремо. Зміст музичного твору відокремлювався від слухача i не вважався продуктом його творчості.

Сучасні дослідники вивчають проблеми розуміння музики в контексті дослідження особливостей формування змісту у свідомості слухача. Когнітивні моделі музичного сприймання, створені наприкінці минулого століття, схильні враховувати й динамічний аспект перероблення музичної інформації. Вони грунтуються на принципі «від загального до часткового», який $\epsilon$ не тільки законом розвитку сприймання в онтогенезі, а й закономірністю актуального становлення образу, коли розуміння музичного образу відбувається від цілого до все більш диференційованих структур $[2 ; 5]$.

Дослідники проблеми розуміння музики вважають, що психологи досить детально вивчають результати рефлексії, але не процес сприймання музики як такий. Відомі дослідження щодо співвідношення адекватності сприймання і механізмів музичного переживання [4]; специфіки музичного мислення; 3'ясування особливостей поведінки слухача $[15 ; 5]$.

Незважаючи на велику кількість досліджень в області сприймання та розуміння музичних творів, до цього часу не створено загальної моделі дослідження процесу розуміння музики.

Мета статті полягає у розробці структури та обгрунтуванні змісту загальної моделі розуміння музичних творів.

Узагальнюючи дослідження в області розуміння мистецтва, В. В. Знаков зазначає, що, не зважаючи на те, що психологія мистецтва викликає загальний інтерес, «в психологічній літературі представлено дуже мало експериментальних, а особливо теоретичних досліджень, присвячених науковому аналізу створення, а також сприймання та розуміння людьми художніх творів» [6, с. 157]. Він виокремлює три взаємопов'язані аспекти «художньої компетентності», та визначає дане поняття як найузагальненішу характеристику розуміючого суб'єкта: когнітивна складність картини світу реципієнта; володіння специфічними «мовами» різних видів, стилів та жанрів мистецтва; наявність системи операціональних навичок та вмінь.

А. Б. Коваленко, аналізуючи структуру розуміння, відштовхується від положень, що грунтуються на системній методології. Вона зазначає: «Проблема розуміння, на наше переконання, відноситься до таких феноменів, аналіз яких доцільно здійснювати на принципах системного підходу. Аналіз діяльності суб'єкта, який включений у процес розуміння, дає змогу описати його структуру у вигляді взаємопов'язаних функціональних компонентів. Це дає змогу розчленувати процес розуміння на складові компоненти, які визначають його перебіг, та проаналізувати кожен 3 них окремо. Застосовуючи системний підхід до аналізу проблеми розуміння, можна виділити щонайменше три базові компоненти: когнітивний, операціональний та регулятивно-особистісний» [9, с. 82]. Модель розуміння, розроблена А.Б. Коваленко, може бути базовою для дослідження розуміння музичних творів при врахуванні деякої специфіки.

Враховуючи особливості музики як об'єкта розуміння, розгляд та аналіз психічних явищ передбачається проводити 3 урахуванням як внутрішніх (суб'єктивних) так і зовнішніх (об'єктивних) чинників. Суб'єкт розуміння розглядається нами, у зв'язку 3 цим, як цілісна особистість, особливості внутрішніх психічних якостей якої виявляються по-різному в залежності від об'єкта розуміння. У ході розуміння музичного твору відбувається включення різних компонентів розуміння - когнітивного, операціонального та регулятивно-особистісного - в регуляцію поведінки суб'єкта діяльності, своєрідність поєднання яких залежить як від суб'єктивно-особистісних характеристик, так і від особливостей музичного твору.

Як було зазначено, всі компоненти даної моделі знаходяться в нерозривній єдності, але для зручності розглянемо їх окремо.

До когнітивного компоненту нами було включено: знання, накопичені суб'єктом (рівень поінформованості у сфері музичного мистецтва): сутності та функції музичного мистецтва; змісту засобів музичної виразності, що опосередковують процес розуміння (форми, жанру); історичних умов, що зумовили появу музичного твору; особливостей особистості композитора; попередній досвід: музично-слуховий та життєвий; суб'єктивні системи смислів (стереотипи, шаблони, установки): стереотип поверхового сприймання; установка на естетичне задоволення.

Інформаційна естетика розглядає сприймання та розуміння художніх (музичних) творів як дії, аналогічні базі знань. База знань визначається як система, що самоорганізується. Вона $є$ рухливою та мінливою у зв'язку з новими даними, тому розуміння будь-якого фрагменту мови вимагає від індивіда звернення до бази даних, що постійно адаптується. Розуміння будьякого висловлювання веде, у свою чергу, до подальшої реорганізації цієї бази даних. 
Вплив музичного досвіду на сприймання та розуміння музики вивчався О. Костюком, Г. Панкевич, Є. Назайкінським, Д. Шелдон та Дж. Пірс. «Для непідготовленого слухача музика - це набір звуків, що відбираються не із обмеженого класу вже відомих звуків, а із нескінченної множини всіх можливих звуків» [12; с. 206]. Теоретично обгрунтував залежність розуміння музики від слухового досвіду А. Сохор: «Слухач може зрозуміти та пережити зміст музики тільки у тому випадку, коли може сприймати звуковий потік не як випадковий та хаотичний, а як організований, осмислений, тобто, такий, в якому відчувається взаємозв'язок та функціональна залежність елементів. Послідовно сприйняті звучання співставляються слухачем 3 усіма їх властивостями. Якщо в зміні однієї або кількох властивостей свідомість виявляє якусь закономірність, то послідовність сприймається як зв'язна, невипадкова, тобто, логічна. Вловивши цю закономірність, слухач отримує можливість «перед-бачити» подальший напрямок процесу. Очевидно, що очікування може виникнути у нас на основі певного досвіду» [13, с. 70-71]. Таким чином, наявний досвід слухання музики робить можливим, на думку А. Сохора, розуміння того, що в музиці називають їі мовою або стилем.

Про неможливість осягнення змісту складних музичних творів без знань, що опосередковують розуміння музики, йдеться в багатьох семіотичних дослідженнях. Так, М. Арановський аналізує механізм переходу позамузичного стимулу у звукове «тіло» за допомогою багатьох стадій опосередкування: «У відомому смислі цей процес можна розглядати як акомодацію (пристосування). Немузичне пристосовується до можливостей музичної мови. Воно формується у свідомості композитора, орієнтуючись на первинну інтрамузичну семантику. Форми акомодації складаються поступово, історично і тому здаються безумовними» [1, с. 121]. Так, для непідготовленого слухача буде незрозумілим значення обраної композитором форми, оскільки цей вибір відмежовує всі інші значення, що не можуть бути вираженими саме цією структурою. Так, рондо не дозволяє розкрити конфліктні відношення, які розкриває соната, передати еволюцію першочергової музичної ідеї, що є специфікою варіацій. Вибір жанру також визначає, певною мірою, межі змісту музичного твору. Що можливо передати оперою, неможливо інструментальною п'єсою. Свою специфіку має культова, побутова музика. Таким чином жанр, форма та програма музичного твору виконують функції породжуючої моделі, що має певний семантичний матеріал. В.Медушевський зазначав, що музичний уривок не може бути сприйнятий як веселий або скорботно-героїчний, якщо його структура не відповідатиме нашим уявленням про веселе чи скорботно-героїчне. Саме відтворення тієї системи уявлень, за допомогою якої «прочитується зміст», і є, на думку В. Медушевського, ключем до аналізу музи- ки, шляхом до розуміння музичного образу, що приховується в структурі музичного тексту.

За Г. В. Іванченко, процеси розуміння музики пов'язані $з$ постійним віднаходженням незнайомого в знайомому та знайомого в незнайомому. Іншими словами, у процесі музичного сприймання постійно відбувається звернення до тезаурусу, до його елементарних та крупніших, ядерних та периферичних одиниць. Під час руху від елементарних смислів до метасмислів, елементарні одиниці категоризуються та інтегруються [7; с. 100].

Підсумуємо наведені положення висловлюванням А. Сохора: «...музику не можна назвати мовою без лапок (тобто, системою умовних знаків). Так, вона говорить нам дещо, але значення «сказаного», включаючи емоції, по-справжньому зрозуміле тільки за умови попереднього засвоєння слухачем хоча б основ виробленої суспільством системи музично-виразних засобів, на яку спирається композитор» [13; с. 193].

Операціональний компонент в структурі розуміння музики включає ті якості суб'єкта, які дозволяють йому успішно здійснювати процедуру розуміння музичного твору, тобто, динамічний бік процесу розуміння, пов'язаний $з$ мислительними тенденціями, що можна об'єднати терміном «стратегія».

Окремо зазначимо, що до цього часу в музичній психології немає чіткого теоретичного розмежування понять стратегіï, способу, типу, форми сприймання та розуміння музики. Існує думка, що сам твір мистецтва визначає способи свого сприймання та розуміння.

Розглянемо декілька класифікацій. Так, М.С. Старчеус було виділено три стратегії: орієнтувально-дослідницьку, орієнтувально-продуктивну та стратегію інтерпретатора. Т. Адорно вважав, що існує два основних способи слухання: експресивнодинамічний та ритміко-просторовий. Н.Л. Нагібіна в результаті дослідження стратегій сприймання музики учнями музичних шкіл виявила 12 стратегій, які об'єднала в чотири «ведучі орієнтації»: когнітивна, переважно-когнітивна, перехідна група та група 3 почуттєвою або переважно-почуттєвою орієнтацією.

А.Б. Коваленко [9;94] під стратегією розуміє досить складне психічне утворення, яке включає дії, пов'язані з підготовкою, плануванням та реалізацією розуміння і здійснюються відповідно 3 індивідуальними особливостями розумової діяльності і конкретними умовами проблеми.

Т. Траверсе [14] вважає, що кожен з етапів слухацької діяльності містить елементи творчості. На всіх етапах процесу слухання можливі різні рівні розуміння музичного матеріалу. Міра розуміння музики, можливість відкриття в ній нового залежать від рівня оволодіння музичним матеріалом, що зумовлює той чи інший етап процесу слухання, відповідно, використання тієї чи іншої стратегії.

Розглянемо стратегії, що складають структуру операціонального компоненту. 
Про найбільш простий рівень розуміння свідчить використання стратегії пошуку аналогів (розуміннявпізнавання, розуміння-пригадування).

На першому етапі слухач обмежується впізнаванням музичного матеріалу, актуалізацією його смислу, сформованого у власному досвіді. У цій пізнавальній ситуації розуміння музичної інформації має форму розуміння-впізнавання.

Результатом неусвідомлюваного впізнавання або пригадування в процесі музичної мисленнєвої діяльності може бути комбінування. На цьому рівні слухацької діяльності відбувається осмислення окремих елементів музичної інформації; співвіднесення власних знань із запропонованою інформацією; доповнення одного виду інформації іншим; перекодування музичного матеріалу на „свою” мову; перехід до іншого рівня осмислення музичного твору в цілому.

На наступному, звуковисотно-інтонаційному рівні увага звертається на музичну мову як на засіб музичної виразності - найбільш узагальнені і найбільш типові зв'язки між звуками, оскільки звук у тій чи іншій музично-мовній системі набуває нових музичних якостей. Процес розуміння музичного матеріалу проявляється у формах розуміння-аналогізування. Показниками розуміння цього рівня $\epsilon$ здатність до порівняння нової музичної інформації 3 наявними знаннями (еталонами, які сформувалися в досвіді на попередньому рівні); виокремлення незрозумілого у новій музичній інформації. В процесі слухацької діяльності відбувається формування художнього образу, породженого сприйнятим музичним матеріалом, створюється інтонаційний фонд, на основі якого осмислюються інтонаційні моделі в розгортанні музичного цілого. При цьому музичне мислення виконує функцію соціально-комунікативного ядра, яке об'єднує в систему створення і засвоєння музичних цінностей. На цьому рівні пізнання процес розуміння набуває вигляду руйнування стереотипів та адекватного, продуктивного розуміння музичного матеріалу.

До регулятивно-особистісного компоненту нами були віднесені: властивості мислення: гнучкість, переважання образного чи вербального способу переробки інформації; індивідуально-типологічні особливості; рівень загального та емочійного інтелекту.

\section{ЛІТЕРАТУРА}

1. Арановский М. Г. Мышление, язык, семантика / М. Г. Арановский // Проблемы музыкального мышления. Сборник статей. Составитель и редактор М.Г.Арановский. М., «Музыка», 1974. - 336 с.

2. Арнхейм Р. Искусство и визуальное восприятие / Р. Арнхейм / Пер. с англ. В. Н. Самохина. - М.: Прогресс, 1974. - 392 с.

3. Беляева-Экземплярская С. Н. Заметки о психологии восприятия времени в музыки / С. Н. Беляева-Экземплярская // Проблемы музыкального мышления: Сб. ст. / Сост. и ред. М. Г. Арановский. - М.: Музыка, 1974. - С. 303-329.
Вплив особистісних якостей на розуміння музичних творів вивчався в межах багатьох психологічних досліджень. Саме відмінності в особистісних характеристиках, що знаходять вираження в типах музичного переживання, є, на думку багатьох дослідників, джерелом нерозуміння.

Так, А. Джильєнд пропонував охарактеризувати тематизм, контрасти, характер музичного твору, визначивши загальний почуттєвий відтінок у судженнях досліджуваних. Є.Гаттевуд досліджував питання семантичної точності слів та висловлювань при оцінці музики досліджуваними 3 різними особистісними характеристиками. Він прийшов до висновку про семантичну єдність слухацьких оцінок, за виключенням оцінок деяких станів та явищ, що важко визначаються.

Л. І. Бочкарьов [4] вивчав залежність адекватності сприймання музичних творів від індивідуальнопсихологічних особливостей особистості та характеру психічних станів досліджуваних. Результати дослідження свідчили, що найбільший негативний вплив на адекватність сприймання здійснюють стани тривожності та депресії.

Музичне мислення $є$ метафоричним, оскільки спрямовує думку до чогось значимого та змістовного. Організовані звукові структури не є самодостатньою цінністю, а певним способом вираження закодованого смислу. Розкодування цього смислу можливе тільки за умови розвинутого інтелекту, що може врахувати контекст певної культури. Б. Асаф'єв зазначав, що музику слухає багато людей, але небагато розуміє, особливо інструментальну. Під інструментальну музику приємно мріяти. Чути так, щоб цінувати мистецтво, - це вже напруження уваги, а, отже, і розумова праця.

Процеси сприймання та розуміння музики супроводжуються переживаннями, в основі яких є знання, відчуття образу та усвідомлення засобів його втілення. Запропонована модель, що включає когнітивний, операціональний та регулятивно-особистісний компоненти, може бути базовою для дослідження процесу розуміння музичних творів.

4. Бочкарев Л.Л. Психологические механизмы музыкального переживания: Дисс.на соискание научной степени докт. псих.наук / Л. Л. Бочкарев. - Киев, 1989.

5. Готсдинер А. Л. Музыкальная психология / А. Л. Готсдинер. - М.: Магистр, 1993. - 263 с.

6. Знаков В. В. Психология понимания: Проблемы и перспективы / В. В. Знаков. - М.: Изд-во «Институт психологии РАН», 2005. - 448 с.

7. Иванченко Г. В. Психология восприятия музыки: подходы, проблемы, перспективы / Г. В. Иванченко. - М.: Смысл, 2001. - 264 с. 
8. Кечхуашвили Г. Н. Бессознательное, установка, музыка / Г. Н. Кечхуашвили, Р. Ш. Эсебуа // Хрестоматия по психологии художественного творчества / Ред.-сост. А. Л. Гройсман. - 2-е изд. - М., 1998. - С. 132-139.

9. Коваленко А. Б. Психологія розуміння / А. Б. Коваленко. - К., 1999. - 184 с.

10. Костюк А. Г. Музыкальное восприятие как предмет комплексного исследования / А. Г. Костюк : Сб. ст. - К.: Муз. Украина, 1986. - 126 с.

11. Моль А. Теория информации и эстетическое восприятие / А. Моль. - М.: Мир, 1966.

12. Назайкинский Е. Музыкальное восприятие как проблема музыкознания / Е. Назайкинский // В кн.

\section{REFERENCES}

1. Aranovskiy, M. G. (1974). Myshleniye, yazyk, semantika [Thinking, language, semantics]. Problemy muzykalnogo myshleniya. Sbornik statey - Problems of musical thinking. Collection of scientific papers. M. G. Aranovskiy (Ed.). Moscow: Music [in Russian].

2. Arnkheim, R. (1974). Iskusstvo $i$ vizualnoye vospriyatiye [Art and visual perception]. (V. N. Samokhin Trans.). Moscow: Progress [in Russian].

3. Belaieva-Ekzemplarskaya, S. N. (1974). Zametki o psikhologii vospriyatiya vremeni i muzyki [Notes about psychology of perception of time and music]. Problemy muzykalnogo myshleniya: Sb. St. - Problems of musical thinking. Collection of scientific papers (pp. 303-329). M. G. Aranovskiy (Ed.). Moscow: Muzyka [in Russian].

4. Bochkarev, L. L. (1989). Psikhologicheskiye mekhanizmy muzykalnogo perezhyvaniya [Psychological mechanisms of musical experience]. Doctor's thesis. Kiev [in Russian].

5. Gotsdiner, A. L. (1993). Muzykalnaya psikhologiya [Music psychology]. Moscow: Magistr [in Russian].

6. Znakov, V. V. (2005). Psikhologiya ponimaniya: Problyemy $i$ perspektivy [Psychology of understanding: Problems and perspectives]. Moscow: publ. "Institut psikhologiyi RAN" [in Russian].

7. Ivanchenko, G. V. (2001). Psikhologiya vospriyatiya muzyki: podkhody, problemy, perspektivy [Psychology of music perception: approaches, problems, perspectives]. Moscow: Smysl [in Russian].

8. Kechkhuashvili, G. N., Esebua, R. Sh. (1998). Bessoznatelnoye, ustanovka, muzyka [Unconscious, attitde, music]. Khrestomatiya po psikhologii khudozhestvennogo tvorchestva - Chrestomathy of psychology of
Восприятие музыки: Сб. статей / Ред.-сост. В.Н.Максимов. - М.: Музыка, 1980, - 256 с.

13. Сохор А.Н. Социальная обусловленность музыкального мышления и восприятия / А.Н. Сохор // Проблемы музыкального мышления. Сборник статей. Составитель и редактор М.Г.Арановский. М., «Музыка», 1974. $-336 \mathrm{c}$.

14. Траверсе Т. Психологічні особливості впливу музичної інформації на особистість слухача / Т. Траверсе // Соц. психологія. - 2005. - № 4. - С. 143-152.

15. Bostrom R. N. Listening behavior: Measurement and application / R.N. Bostrom. - New York: Guilford Press, 1990.

artistic creativity. A. L. Groisman (Ed.). $2^{\text {nd }}$ ed. Moscow [in Russian].

9. Kovalenko, A. B. (1999). Psykholohiya rozumunnya [Psychology of understanding]. Kyiv [in Ukrainian].

10. Kostyuk, A. G. (1986). Muzykalnoye vospriyatiye kak predmet kompleksnogo issledovaniya: Sb. st. [Music perception as a subject of complex study: collection of scientific papers]. Kiev: Muz. Ukraina [in Russian].

11. Mol, A. (1966). Teoriya informatsii $i$ esteticheskoye vospriyatiie [Information theory and esthetic perception]. Moscow: Mir [in Russian].

12. Nazaikinskiy, E. (1980). Muzykalnoie vospriyatiie kak problema muzykoznaniia [Music perception as a musicology problem]. Vospiyatiye muzyki: Sb. statei Music perception: collection of scientific works. V. N. Maksimov (Ed.). Moscow: Muzyka [in Russian].

13. Sokhor, A. N. (1974). Sotsyalnaia obuslovlennost muzykalnogo myshleniia i vospriiatiia [Social conditionality of music thinking and perception]. Problemy muzykalnogo myshleniya. Sbornik statey. - Issues of music thinking and perception: collaction of scientific papers. M. G. Aranovskiy (Ed.). Moscow: "Muzyka" [in Russian].

14. Traverse, T. (2005). Psykhologichni osoblyvosti vplyvu muzychnoyi informatsiyi na osobystist' slukhacha [Psychological features of music information influence on listener's personality]. Sots. Psykhologiya - Social psychology. (pp. 143-152) [in Ukrainian].

15. Bostrom, R. N. (1990). Listening behavior: Measurement and application. New York: Guilford Press [in English]. 
Алла Леонидовна Весельская,

ассистент кафедры социальной и практической психологии, Житомирский государственный университет имени Ивана Франко, ул. Большая Бердичевская, 40, г. Житомир, Украина

\section{ПСИХОЛОГИЧЕСКАЯ МОДЕЛЬ ПОНИМАНИЯ МУЗЫКАЛЬНЫХ ПРОИЗВЕДЕНИЙ: СТРУКТУРА И КОМПОНЕНТНЫЙ СОСТАВ}

Рост объема музыкальной информации, которую человек воспринимает в повседневной жизни, определяет актуальность исследования процессов восприятия и понимания. Музыка тиражируется в повседневной жизни средствами массовой информации, используется как фон для подачи информации, например, в рекламе; становится средством общения в молодежных субкультурах. Понимание музыкального произведения - это сложный процесс, где сочетаются эмоциональная и интеллектуальная стороны, содержание музыкального материала и особенности личности. Это единство усложняет процесс понимания и обусловливает необходимость в структурировании и уточнении компонентов общей модели понимания, которая и определяет специфику и результативность восприятия произведений искусства. В общем виде, проблема восприятия и понимания музыки раскрывается в исследованиях в различных областях психологии: психофизиологии, музыкальной психологии, психологии искусства и т. п. Существующие модели восприятия музыки основываются на сравнительной структуре перцептивного акта, отражают многомерность и многоуровневость музыкального произведения. Слушательскую деятельность представляют и как слуховой анализ произведения, где единицей измерения является звуковой объект, и как процесс схематизации и упрощения информации, которая объективно содержится в музыкальном произведении. Цель статьи - проанализировать структуру и содержание общей модели понимания музыкальных произведений. Предлагаемая модель понимания музыкальных произведений включает когнитивный, операциональный и регулятивно-личностный компоненты. Когнитивный компонент включает: знания, накопленные субъектом (уровень осведомленности в сфере музыкального искусства): сущности и функции музыкального искусства; содержания средств музыкальной выразительности, которые опосредуют процесс понимания (формы, жанра); исторических условий, обусловивших появление музыкального произведения; особенностей личности композитора; предыдущий опыт: музыкально-слуховой и жизненный опыт; субъективные системы смыслов (стереотипы, шаблоны, установки): стереотип поверхностного восприятия; установка на эстетическое удовольствие. Операциональный компонент в структуре понимания музыки включает те качества субъекта, которые позволяют ему успешно осуществлять процедуру понимания музыкального произведения, то есть динамичную сторону процесса понимания, связанную с мыслительными тенденциями, которые можно объединить термином «стратегия»: поиск аналогов, комбинирование, гибкая стратегия, продуктивная. Регулятивно-личностный компонент включает: свойства мышления: гибкость, преобладание образного или вербального способа переработки информации; индивидуально-типологические особенности; уровень общего и эмоционального интеллекта. Предложенная модель, включающая когнитивный, операциональный и регулятивноличностный компоненты, может быть базовой для исследования процесса понимания музыкальных произведений.

Ключевые слова: понимание музыкальных произведений, структура понимания, когнитивный, операциональный и регулятивно-личностный компоненты понимания.

\section{Alla Veselska, assistant of the Department of Social and Applied Psychology, Zhytomyr State University named after Ivan Franko, 40, Velyka Berdychivska Str., Zhytomyr, Ukraine}

\section{PSYCHOLOGICAL MODEL OF UNDERSTANDING \\ A MUSICAL COMPOSITION: STRUCTURE AND COMPONENTS}

The article is aimed at analysing the structure and content of the general model of musical compositions understanding. The increasing amount of musical information perceived by people in everyday life determines the relevance of researching the processes of perception and understanding of music. Music is reproduced in daily life by the media, it is used as the background for the presentation of information, for example, in advertising; it is a means of communication for youth subcultures. The understanding of a musical composition is a complex process, where the emotional and intellectual aspects are combined along with the content of musical material and personality traits. This unity complicates the understanding and necessitates structuring and refining the components of a common model of understanding, which determines the specificity and efficiency of art perception. In general, the issue of perception and understanding of a musical composition is revealed in studies of various fields of psychology: neuroscience, music psychology, psychology of art etc. The existing models of music perception are based on comparable structure of perceptual act that reflects multidimensionality and multilevel character of a music composition. Listening is considered both as auditory 
analysis of a composition, where the unit is a sound object, and as a process of schematisation and simplification of the information contained in a musical composition. The model of music understanding, including cognitive, operational and regulatory-personal components, has been offered. The cognitive component includes knowledge accumulated by a subject (awareness in the field of music): the nature and functions of music art; contents of means of musical expression that mediates the process of understanding (form, genre); history of the emergence of a musical composition; personality traits of a composer; previous experience: auditory and life experience; subjective systems of meanings (stereotypes, attitudes): superficial stereotype perception; focusing on aesthetic pleasure from a musical composition. The operational component of the structure of music understanding includes those subject properties that make it possible to successfully perform the procedure of understanding a musical composition. The regulatory and personal component includes properties of thinking: flexibility, the prevalence of verbal or figurative way of information processing; individuallytypological features; the level of general and emotional intelligence.

Keywords: music understanding, understanding structure, cognitive, operational and regulatory-personal understanding.

Подано до редакиії 28.04.2016

УДК: $304.2+159.98$

Ольга Олегівна Водолазська,

кандидат психологічних наук, доцент кафедри загальної та диференціальної психології, Південноукраїнський національний педагогічний університет імені К. Д. Уиинського, вул. Фонтанська дорога, 4, м. Одеса, Україна

\section{САМОРЕГУЛЯЦІЯ У ПРОФЕСІЙНОМУ СТАНОВЛЕННІ МАЙБУТНЬОГО ФАХІВЦЯ}

У статті викладено результати теоретико-емпіричного дослідження саморегуляції як чинника професійного становлення майбутнього фахівия - психолога. Представлено аналіз значущих кореляційних зв 'язків між показниками мотивації досягнення, властивостей особистості та показниками складових саморегуляції: самоактуалізації та сенсожиттєвих орієнтацій. Візуальний аналіз представлених профілів дозволив скласти психологічні портрети представників гуманітарної та технічної спрямованості. Доведено, що саморегуляція є домінуючим чинником професійного становлення майбутнього фахівия - психолога.

Ключові слова: саморегуляція, професійне становлення, особистість, самоактуалізація, мотиваџія, сенсожиттєві орієнтаціï.

Для людини професія - це джерело існування і засіб особистісної самореалізації. На сучасному етапі соціально-економічного розвитку суспільства важливою $є$ проблема професійної підготовки майбутнього практичного психолога, що передбачає формування його як активного суб'єкта діяльності і потребує, поперше, належного рівня підготовки, по-друге, високої відповідальності за результати своєї професійної діяльності.

Аналіз досліджень К.О. АбульхановоїСлавської, Б.Г. Ананьєва, О.О. Бо-дальова та інших вчених свідчить про визначення основних умов вільного володіння професійною діяльністю, які можуть бути представлені трьома групами показників: змістовних - знання теоретичної психології, відношення, установки і ціннісна орієнтація; емоційних - припускають уміння відображати, аналізувати, співпереживати ситуацію з позицій професійної діяльності; діяльнісних - відображають функціональну сторону розвитку професійної культури практичного психолога. Як відзначає О.П. Саннікова [8, с.195], успіх будь- якої діяльності залежить переважно від трьох головних факторів: якості спеціальних знань та вмінь, сили і стійкості професійної мотивації, організації психофізіологічної структури діяльності. Загалом, Б.Г. Ананьєв, Л. І. Божович, Г.С. Костюк, Є.О. Клімов, О.М. Леонтьєв, Б.Ф. Ломов, Л.А. Люблінська, В.М. Мясіщев, С.Л. Рубінштейн, В.В. Чебишева, розглядаючи процес професійного становлення особистості, спираються на принцип єдності свідомості і особистості у діяльності, розуміючи професійне становлення особистості як складову іiі загального розвитку [8, с. 94].

За думкою С.Я. Батишева, професійна підготовленість спеціаліста повинна передбачати розвиток у нього саморегуляції як психологічного механізму, який забезпечує його професійну діяльність. Психологічний супровід професійної освіти може виступати у якості технології, яка забезпечує надійність професійної діяльності спеціаліста. При цьому, важливим принципом психологічного супроводу $\epsilon$ визнання права суб'єкта освіти самому приймати рішення про 